\title{
Entrevista: Arakcy Martins Rodrigues
}

\begin{abstract}
Nesta entrevista, realizada no primeiro dia de setembro de 1999, Arakcy Martins Rodrigues, professora do Departamento de Psicologia Social e do Trabalho do Instituto de Psicologia da USP, fala-nos sobre pesquisa, trabalho, organizações e psicologia social. Apresenta-nos suas reflexões com generosidade, marcadas pela sinceridade, bom humor e seu jeito próprio de criar imagens. Reporta-se à sua experiência em pesquisa e atuação como professora de psicologia na Escola de Administração de Empresas de São Paulo da Fundação Getúlio Vargas. Participaram dessa conversa Leny Sato e Fábio de Oliveira.
\end{abstract}

Leny Sato - Aracky, os Cadernos de Psicologia Social do Trabalho foram inicialmente criados visando abrir um espaço para publicação de trabalhos de alunos que desenvolveram, no CPAT, trabalhos como estágio das disciplinas Seleção Profissional I e II. São, em geral, as mini-pesquisas.

Arakcy Martins Rodrigues - Só no estágio eles chegam a fazer mini-pesquisas... e vivem por aqui, cada cara inteligente, interessado...

$\mathrm{L}-\mathrm{Tem}$ alguns alunos que se interessam por questões mais sociais.

A - Que bacana...

L - Propomos três temas de pesquisa, não é, Fábio? O Fábio é quem em geral supervisiona esses trabalhos... Além dos interesses dos alunos, tem toda a questão de trabalhar em grupo com os alunos... e isso não é fácil.

A - E também a pesquisa é um trabalhinho de formiga, uma boa parte dela... Porque, eles vêm, os mais ideologizados, vamos dizer assim, vêm com grandes ideais, grandes frases na cabeça de grandes autores de esquerda e, de repente, para eles, esse trabalhinho cotidiano... Não, tem que ir lá procurar o cara... tem que ir prá Freguesia do Ó, não sei o quê...esse trabalhinho...

Fábio de Oliveira - Eles acabam desanimando...

A - Ele veio para pontificar, ele pensa que... veio fazer o socialismo e chega aqui ele encontra o trabalho de formiga e de carregar pedras. E pesquisa é isso. E ela também não diz sim nem não, não é? Quando se está fora da esfera da ciência, entrar no campo da pesquisa é muito frustrante, ainda mais quando se idealiza a ciência. Ciência é quando você descobre que 60\% é assim, 40\% é assado e então ganha a coisa dos 60\% e olha lá! Nunca é $100 \%$ e zero por cento... quer dizer, é aquela coisa toda da probabilidade, daquela explicação que custa para você realmente fazer uma afirmação. Em um trabalho de pesquisa, isso é uma ousadia que você tem que fazer com muito cuidado, depois de pesquisar. Essa idéia me veio com o Flávio Pierucci... eu fui ao PRODIR ${ }^{25}$ fazer uma palestra sobre o discurso livre e quando acabou o Flávio me disse: "Adorei você mostrar que pesquisa é aquele trequinho em que cada detalhe importa" [risos], a pesquisa empírica. Porque, na verdade, o Brasil tem uma tradição de ensaios que combina muito com a ideologia da intelectualidade das ciências sociais e humanas, ideologia que resultou na produção de ensaios. Na verdade o trabalho empírico era altamente desprezado. Vocês são muito jovens, não se lembrariam disso.

F - Na psicologia também?

${ }^{25}$ Programa de Doação de Bolsas de Pesquisa a Fundação Carlos Chagas. Os recursos vêm da Fundação Ford e da Fundação McArthur. 
A - Não. Principalmente em sociologia. A psicologia nem entrava... nem existia nas contas das grandes confabulações intelectualizadas, mesmo aqui na USP.

L - Era uma coisinha...

A - Não. Era o indivíduo, era do micro. Nós cuidávamos do micro, do individual... E nós nem tínhamos formação em pesquisa, até hoje não temos... E o mais grave, além de não saber fazer pesquisa empírica, nós tínhamos desprezo: "aquilo era positivismo", aquilo era inclusive "coisa de americano". Era altamente suspeito você usar o empírico, os números eram suspeitos, eram "americanos". Inclusive eu e a Tina ${ }^{26}$ escrevemos uma vez um comentário sobre isso. Então, havia repulsa. Vocês imaginem: ignorância mais repulsa... E, por alguma razão, não sei porque, eu sempre estive presente nas primeiras coisas de pesquisa que pintaram. Em pesquisa de mercado eu estive, mas muito pouco, mas quando fizeram o CESIT $^{27}$, o Leôncio ${ }^{28}$ acabou coordenando. O CESIT foi aqui, na Sociologia, é um centro de sociologia do trabalho. Começou com um americano, começou com um grande survey. Não sei em quantas indústrias, um questionário daqueles quilométricos que sempre fazemos quando somos principiantes em pesquisa... Era um grupo de mestrandos promissores do Florestan Fernandes e cada um ia interpretar algumas das perguntas desse grande survey. $\mathrm{O}$ mestrado do Leôncio sai desse trabalho: Conflito industrial e Sindicalismo no Brasil ${ }^{29}$. Esse foi o seu primeiro livro, são algumas perguntas desse grande survey que ele interpreta. Havia um grupo muito bom de mestrandos promissores e o Leôncio acabou dirigindo o CESIT. As pessoas entravam para o CESIT, mas tinham o sonho de dar aula. Era como um trampolim porque ele era muito subestimado. Também não sei qual era a situação estatutária deles. Mas muita gente entrou via CESIT e depois foi para o departamento. Muitos mestrandos fizeram seus mestrados com esse survey e depois fizeram pesquisas maiores. Mais tarde alugou-se uma casa na Rua Cristiano Viana onde ele passou a funcionar. Então, eu estive ao lado disso. Quando aqui em São Paulo abriu-se o Centro Regional de Pesquisas Educacionais - foi uma das primeiras coisas a funcionar aqui na Cidade Universitária - que era uma autarquia federal dirigida pelo Fernando de Azevedo... Vocês imaginem, eu estava no terceiro ano, eu e minhas amigas, nós éramos um grupo que fez tudo junto durante muito tempo...

F - Você fez a graduação em filosofia.

A - Filosofia. Mas havia muitas matérias de psicologia, você sabe.

L - Em que ano você estudou Arakcy?

A - De 56 a 59. Eu fui colega ano a ano da Sylvia Leser de Mello, e de outras gracinhas: Bento Prado Júnior, Lúcia Prado. Minha turma foi maravilhosa... minha inesquecível turma de graduação.

Um dos nossos professores de psicologia era o Dante Moreira Leite. Eu já tinha tido a sorte de ter o Dante como professor, imaginem vocês, no Mackenzie, que era uma escola tradicional... tínhamos psicologia no científico... eu tive muita sorte durante o meu científico, pois um monte de gente da Maria Antonia veio dar aulas no Mackenzie. Eu peguei, meu Deus do céu: Norman Potter, Mário Leônidas Casanova, Nilo Scalzo, Neif Safady, Dante Moreira Leite. E peguei a idéia de vir para cá. Parecia que eu tinha descoberto a minha tribo: eu sempre li muito, desde criança eu li muito, devorava os livros. Quando eu encontrei essas pessoas, eu achei que tinha encontrado minha linguagem, minha terra... [risos]. Foi incrível! Já no Mackenzie, no terceiro ano científico, o meu pai me deixava na Rua Itambé e eu

\footnotetext{
${ }^{26}$ Albertina de Oliveira Costa, pesquisadora da Fundação Carlos Chagas.

${ }^{27}$ Centro de Sociologia Industrial e do Trabalho, anexo ao Departamento de Sociologia da FFLCH da USP.

28 Refere-se ao Prof. Leôncio Martins Rodrigues, seu marido.

${ }^{29}$ Publicado em São Paulo pela Difusão Européia do Livro, em 1966.
} 
atravessava a rua e ia para o grêmio da Faculdade Maria Antônia o ano inteirinho. Peguei segunda chamada em todas as matérias por falta.

O fato é que o Dante Moreira Leite escolheu quatro de nós - as promissoras do terceiro ano [risos] - e trouxe-nos para o Centro porque ele ia dirigir todo um setor. Havia dois grandes setores e ele foi convidado para coordenar um deles. E nós, felicíssimas porque íamos trabalhar com o Dante. Fomos convidadas como auxiliares de pesquisa. Bom, foi uma decepção por mil razões... também, nós fizemos uma farra porque nunca tínhamos trabalhado na vida e fazíamos todo tipo de impertinência possível, impertinência em relação a algumas bobagens que as chefes faziam, sempre discussões intelectuais. Mas já estava eu lá envolvida com coisas de pesquisa. Depois passamos para o setor que era o dos homens, os estatísticos. Havia seções que eram a "casa de Bernarda Alba" - só mulheres - e nós fomos parar na turma dos homens. Homens bravos, estatísticos... Estatística era o maior terror e eu ficava numa máquina enorme, super barulhenta, só elevando ao quadrado uma lista infindável de números...

L - Por que tinha que elevar ao quadrado?

A - Porque devia ser cálculo de qui-quadrado, eu imagino. Nunca ninguém me explicou. Anos depois, décadas depois, quando eu fui estudar estatística e vi o cálculo de quiquadrado, pensei: "Já sei, eu calculava o qui-quadrado, pedaços do qui-quadrado!". Estive nessa canoa de pesquisa também... São coisas que pintam...

L - Mas na graduação em filosofia não tinha pesquisa empírica. Era filosofia...

A - Nada, nada de pesquisa... Era filosofia! Em Lógica da Ciência a gente estudava o que eram as ciências dedutivas, o que era indução, o que era o empírico [risos]. Nós pelo menos sabíamos o que queria dizer "empírico"! Mas no Centro Regional de Pesquisas Educacionais (CRPE), a toda hora nós começávamos uma pesquisa nova, ninguém tinha analisado as antigas ainda, ninguém sabia o que fazer com aqueles questionários, questionários mais mal pensados... A turma dos homens, eles tinham que passar pela nossa sala prá ir à lanchonete. Então, a piada que eles tinham inventado sobre o meu grupo era assim: que quando eles passavam a primeira vez prá ir tomar o café, eles ouviam da nossa sala, o seguinte: "vamos fazer uma pesquisa?" e que na volta nós estávamos grampeando questionários [risos]. Também, por alguma razão, eu estive numa fronteira de pesquisa de mercado. O Leôncio e minha irmã estiveram na Marplan e uma vez eu fiz um freelance para a Marplan. Eu fui fazer análise para começar minha formação psicanalítica e precisava de dinheiro. Entrei na Alcântara Machado, que era fervilhante, muito entusiasmante naquele momento, e fiz uma carreira de onze meses inacreditável: entrei como revisora e saí como chefe de três departamentos. Só não cheguei a trabalhar efetivamente como chefe desses três departamentos. Meu salário, mesmo tendo sido multiplicado por dez, ainda estava muito aquém do que as estrelas ganhavam em outras agências e nas outras firmas de pesquisa de mercado. Saí porque eu não podia me desligar da clínica psicológica, então fui parar no INPC ganhando uma miséria de salário. Depois fui parar no Serviço de Higiene Mental Escolar, que pertencia à Secretaria de Educação.

L - Mas aí, Arakcy, você foi aprender a fazer pesquisa "fazendo"?

A - É. Tendo caído nos poucos cantos onde havia pesquisa no mundo acadêmico na época: CESIT, CRPE e um pouco também "metendo o bedelho" em pesquisa de mercado. Pesquisa de mercado já existia, mas na vida acadêmica tinha poucas coisas e eu, não sei porquê, caí nas poucas coisas que existiam. Mais tarde, em 1965, fui convidada para participar de uma grande pesquisa multidisciplinar sobre reprodução humana, num Centro de Dinâmica Populacional (CEDIP) anexo ao Departamento de Estatística Aplicada, na Faculdade de Saúde Pública. Nunca vi um psicólogo participando de uma pesquisa desse tipo, e o convite feito a mim só podia ter partido de um intelectual perfeito, inovador, como o Prof. 
Cândido Procópio de Camargo. Além dele, eu trabalhava com o Paul Singer, a Elza Berquó, o João Yunes, a Maria Lucila Milanesi... e havia o grupo mais jovem, de sociólogos, antropólogos, do qual eu fazia parte. Em 1969, com a aposentadoria, pelo governo, de alguns professores, e com a reestruturação da universidade, o CEDIP acabou e eu fui com a Elza Berquó, o Procópio Camargo e o Paul Singer continuar a pesquisa de fertilidade no CEBRAP, onde fiquei quase cinco anos.

Retomando, na formação de hoje, o que eu acho que a gente tem muito pouco é técnica de observação controlada, que é iminentemente das Ciências Sociais e que é totalmente desprezada pelos experimentalistas. Não sei se aqui no Instituto... Os psicólogos experimentalistas acreditam que aquilo não é ciência, quando temos a mesma possibilidade de exercer rigor científico com as duas técnicas, se soubermos trabalhar, tanto na experimental quanto na de observação controlada. Só não se pode mexer nas variáveis, mas você as isola, você tabula só assim, tabula só assado, você está fazendo o mesmo que o experimentalista que diminui a luz, aumenta o barulho ou qualquer coisa parecida, só que é ex post facto, é depois do fato ocorrido. Você não mexeu em nenhuma variável, mas se souber brincar, pode brincar com todas as variáveis, ainda mais com os testes estatísticos...

F - É como fazia o Stuart Mill, comparando sociedades. Ele controlava variáveis sem... aqui tem e aqui não tem um determinado fator, mas sem mexer nelas.

A - Vamos para algo mais simples... você pega uma pesquisa eleitoral, aí você diz, as mulheres mais velhas são malufistas, então você fala: "que engraçado, por que será que mulher mais velha gosta do Maluf?" Aí eu chego para você e digo: "Não é, velho. Tem uma terceira variável que você não está enxergando. É que as mulheres das gerações passadas não eram escolarizadas. Você tem a variável escolarização por trás disso". Na verdade, toda a diferença, toda a variação que você está atribuindo à idade é determinada, parcialmente, pela escolarização. Aí, o que você faz? Separa por escolaridade e por idade. É como se estivéssemos mexendo no campo experimental. Se você souber fazer isso, você tem o mesmo rigor científico, que é a principal característica do pensamento científico. Mas para os alunos fica a idéia de que a pesquisa é sempre experimental. dos ensaios.

L - É interessante o que você falou, de que existia um desprezo pela pesquisa a favor

A - Desprezo, realmente desprezo... Até pouco tempo atrás, no próprio CEBRAP, nós fomos chamados à ordem porque estávamos fazendo pesquisa americanizada e não era verdade. Não era americanizada. Nós, na verdade, trabalhávamos com pesquisa quantitativa, tínhamos uma especialista em amostragem que era da Faculdade de Saúde Pública, uma das pessoas da equipe.

Mas, voltando ao outro assunto, o fato é que tinha tudo isso. Tinha muito despreparo para a pesquisa. Mesmo eu que tinha matérias de psicologia dentro da filosofia. O Joel Martins, que era um experimentalista fanático e depois virou fenomenólogo, batia a mão na mesa e dizia: "Não existem métodos. Existe método, método, método!!!". Como se nós estivéssemos dizendo o contrário... E nós íamos para a Alameda Glete trabalhar com os ratos dentro do curso de filosofia. Vocês não imaginam o que dava na nossa cabeça... Os ratos lá e ciência era aquilo, psicologia científica era aquilo. Desse modo, nós filósofos não íamos nos interessar por números mesmo.

L - Arakcy, fala, como sugeriu o Fábio, como você entrou para a área de trabalho?

$A$ - Eu fico sabendo que tem um concurso da $G^{30}$. Fiz o meu doutorado ${ }^{31}$ aos

${ }^{30}$ Escola de Administração de Empresas de São Paulo da Fundação Getúlio Vargas. 
trancos e barrancos ${ }^{32}$. Eu fico sabendo que tem um concurso público na GV, de psicologia do trabalho, psicologia aplicada à administração. Nunca tinha ouvido uma frase sobre isso! Eu não tive curso disso, nunca! E vinha uma banca examinadora de fora para fazer o concurso porque na GV não havia ainda doutores na área de psicologia para me examinar. Gente! Eu fui pegar os livros de dois desses professores que vinham de fora e tinham livros publicados aqui, mas não dava, eu não conseguia ler os livros, mesmo sabendo que seu autor estaria na minha banca. Eu não conseguia ler! Um era sobre os grupos de sensibilização, de uma mulher... você não sabe o que é isso! O outro era um cognitivista (um tema de seu livro caiu na minha aula pública) e tinha o Aroldo Rodrigues. $\mathrm{O}$ Aroldo e a professora não puderam vir, então colocaram o Dante Moreira Leite. Quando eu me inscrevi no concurso, eu cheguei aqui e achei o Dante. Falei: "Dante, eu não sei uma palavra!". Eu não conhecia Krech e Crutchfield ${ }^{33}$. Tudo isso se desenvolveu depois que eu saí da escola, em 60. Eu havia passado os últimos treze anos fazendo formação na Sociedade Brasileira de Psicanálise de São Paulo e pesquisando fertilidade humana. O Dante meio "impressionadão" e eu fazendo piadas. Só que, pelo amor de Deus, eu contei toda a minha ignorância para o Dante e ele estava na banca. Veio ele e o outro examinador. Eu lia as coisas do concurso. Olha, eu acho que eles me aprovaram porque apostaram num potencial. Puseram-me lá. Eu tentei fazer um Centro de Psicologia. Eu vi que centro não ia sair nada. Então, soube que tinha esse Núcleo de Pesquisas e Publicações e entrei, pedi um dinheiro. Como eu tinha trabalhos com mulher, de uma maneira muito ampla na pesquisa sobre fertilidade, eu pedi verba para pesquisa sobre trabalho feminino e desde então eu estudo o tema do trabalho feminino ${ }^{34}$, sempre com as verbas pequenas desse núcleo de pesquisa. O fato é que aí eu me defronto com o trabalho. Eu não consigo ler os livros da teoria gerencial americana. Eu não consigo ler. Nem para o concurso nem depois do concurso nem prá preparar aula. Eu não consigo ler... Havia uma disciplina de primeiro ano que é Introdução à Psicologia. Eu me refugiei nesse primeiro ano. Em compensação, eu ensinava behaviorismo, gestalt, psicanálise e ainda podia escolher uma lista de autores para o trabalho do semestre. Eu me matava, fazia apostilas de tudo isso... a de gestalt circula por aí até hoje, não é? A de psicanálise também. Refugiava-me nessa disciplina e tentava estudar para a disciplina seguinte, que era... olha o nome: Psicologia Aplicada à Administração! Tento lecionar, mas também não consigo. Aí eu estou francamente pensando em ir embora, quando chega o Peter Spink. Deus olha prá mim, fica com pena e me manda o Peter Spink para São Paulo. Às vezes Deus olha prá mim e fica com pena e me manda alguma coisa [risos].

L - Mas antes de falar do Peter, fala por que você não conseguia estudar esses textos...

A - Depois eu os li. Eles são normativos. Ciência não é normativa. Eu não conseguia engolir uma frase daquilo (eu preciso procurar uma citação em que o Althusser analisa a linguagem que esses livros usam). Não só a coisa era bobagem, como a maneira de dizer era boba, não tinha fundamento nenhum. Eu nem era de esquerda nem fanática - claro que eu tenho uma coisa voltada, não sei se para a esquerda, mas para o povo [risos]. Eu não consigo ler... Eu entendo mais se você me der um parágrafo daqueles alemães malucos com um parágrafo de trinta e cinco linhas e diversas frases coordenadas e subordinadas etc... esses eu entendo. Se você me der tudo em forma esquemática, eu não entendo, eu não guardo. Dizem

\footnotetext{
${ }^{31}$ Intitulado Estudo sobre as mulheres que geraram um nascido vivo durante uma pesquisa prospectiva.

32 Nascimento do meu filho caçula, diagnóstico de câncer no meu útero durante o puerpério...

${ }^{33}$ A entrevistada refere-se ao livro $O$ indivíduo na sociedade - um manual de psicologia social, de Krech, Crutchfield e Ballachey, publicado originalmente em 1963, traduzido por Dante Moreira Leite em 1973 e publicado pela Editora Pioneira, em São Paulo.

34 Uma das pesquisas da entrevistada resultou no livro Operário, Operária - estudo exploratório sobre o operariado industrial da Grande São Paulo, publicado pela Editora Símbolo, em 1978, São Paulo.
} 
que aquela maneira é mais fácil, que se aprende logo, mas, com qualquer texto assim, eu não só não consigo ler, como se me obrigarem a ler eu esqueço em cinco minutos. Aliás, isso é explicado pela Gestalt. Então, tem uma série de fatores... eu não sabia por que eu não gostava. Eu me xingava de vagabunda e outros nomes... Mas vejam, as paredes têm ouvidos: você está lá na sua sala, refugiada em Introdução à Psicologia, mas você está na Congregação, você está na reunião de departamento, nos corredores, no elevador. Então, você começa a sacar o que a faculdade estuda...

Hoje eu sei porque eu não conseguia ler esses livros. Absurdos como a grande pesquisa de Hawthorne, Western Eletric. Eles põem seis variáveis e nas conclusões nenhuma das variáveis que eles põem entram. É como se eu fizesse assim: ponho leite condensado, ovos, bato e quero que saia uma pizza. Os ingredientes que eles puseram não podem dar naquelas conclusões. Da tarefa também não falavam! E coisas desse tipo. É difícil você ter, sozinha... Você tá vendo que em volta o que circula é isso: cinco dias de Lindóia ${ }^{35}$, você entra líder autoritário e sai líder democrático. Vejam, qual é a postura que você adota para ler um livro científico? A de aprender, não é? Mas como isso seria possível para mim, se eu não aceitava nada daquilo, do conceito de homem que, queiram ou não, está implícito ou explícito em toda teoria de organização? Mas em nome de que eu não aceito? Sim, seria em nome da Gestalt, da Psicanálise etc. Mas, depois que eu estudei a Escola Sociotécnica, minhas referências se ampliaram: antes de mais nada, a tarefa. Mas aí chega o Peter Spink e organizo um seminário de professores.

\section{L - Veio visitar?}

A - Ele vinha e ia. Ele era o diretor do Tavistock Institute of Human Relations.

L - Em que ano, Arakcy?

A - Eu começo na GV em 1974. Fico refugiada até 1977. Há alguns mal entendidos no primeiro dia do seminário. Na segunda aula, tem um décimo de pessoas. A Tereza Fleury, que leciona no mesmo departamento que eu, pergunta se podia convidar seu marido, Afonso $^{36}$, engenheiro, para participar e eu fiquei conhecendo o Afonso, que foi em todas as aulas. Ele me salvou porque o Peter terminou e sobraram eu, o Afonso e o Sigmar ${ }^{37}$. Em seguida o Peter organiza um curso de pós-graduação do qual participei. Eu sentava na carteira como uma aluninha. Comprei caderno novo, escrevia "Professor Peter Spink" e ficava quietinha escutando e a cada aula ele distribuía textos (ele tinha trazido pilhas de coisas, seja de congressos, seja capítulos de livros, seja artigo, a cada aula, tudo em inglês). Depois desse curso eu consegui ler teoria gerencial, pois foi quando eu entendi onde esses autores estavam num mapeamento maior na minha cabeça, "ah, essa é aquela turma... ah, essa é taylorista... ah, essa é aquela turma de RH” [risos]. Depois de ter visto a Escola Sociotécnica, o Eric Trist, falando dessa gente, aí eu consegui ler e leio tudo isso aí e ousei chegar em Psicologia Aplicada à Administração com um programa de dois anos, um programa que não cabia em um semestre. Esses alunos já tinham estudado teoria geral da administração e eu soube que os professores dessa matéria ensinavam Taylor seriamente, como sendo o que deveria ser feito, e alguns até chegavam na escola de relações humanas... outros não, não dava tempo... era assim: "como é administrar cientificamente". Eu ofereci o curso, começei a lecionar Psicologia Aplicada à Administração. Também dei cursos no mestrado. Traduzi todos os capítulos do Systems of Organization ${ }^{38}$ com a ajuda de uma turma de alunos do mestrado.

\footnotetext{
${ }^{35}$ A entrevistada refere-se a seminários e treinamentos gerenciais em hotéis na cidade de Águas de Lindóia, em São Paulo.

${ }^{36}$ Trata-se de Afonso Fleury, professor do Departamento de Engenharia de Produção da Escola Politécnica da USP.

${ }^{37}$ Sigmar Malvezzi, professor do Instituto de Psicologia da USP, da PUC-SP e da FGV.

${ }^{38}$ Dos autores E. J. Miller e A. K. Rice, publicado em Londres pela Tavistock Publications em 1967.
} 
Havia uma carência total de textos da escola em português. Eu traduzi algumas coisas para meus alunos. Aí, eu me apaixono completamente. Finalmente estamos falando a minha língua! Eu gosto de pensamento inglês. Eu já estava no pensamento inglês na psicanálise, mas quando cheguei em administração, achei que tinha que dar a volta ao mundo e, principalmente, pensei que tinha que ir para a América. Aí, eu volto e fico no prédio ao lado porque o Tavistock of Human Relations fica ao lado do Tavistock of Psychoanalysis, que era tudo o que eu tinha estudado em psicanálise. Esse livro, Systems of Organization, depois de uma parte teórica muito boa, ele tem casos. É um livro fascinante. E ele desvenda para mim um grande mistério. Ele diz que a teoria gerencial americana freqüentemente não funciona quando fazemos consultorias ou assessorias porque ela, na verdade, é parcial, só foi construída a partir de estudos empíricos na indústria e depois se alçou a ser algo generalizável, como se fosse uma teoria das organizações em geral. Acontece que a indústria tem uma especificidade, que é a seguinte: as fronteiras da organização coincidem com as fronteiras físicas da organização. São duas fronteiras justapostas. Você não sabe que são dois traços porque um esconde o outro. Ao passo que todas as situações em que nossas intervenções não dão certo, são justamente as situações em que essas fronteiras não coincidem. O que faz o Tavistock? Faz aquilo que a gente chama de "duplo uso" para quem quiser contratar seus serviços, geralmente o governo britânico, ao mesmo tempo que presta assessorias, cada "encomenda" que cai lá é tratada cientificamente pela equipe. A equipe tem, paralelamente, reuniões que discutem o trabalho de campo que se fez na empresa. Eles não ficam só aplicando técnicas como aqui, reproduzindo o taylorismo (aliás, agora, aqui, estão modernizando hospitais e "modernizar" tem significado "taylorizar").

L - E, na verdade, Arakcy, vemos muito um discurso que é assim... uma visão de teoria que é assim: o taylorismo foi, mas já "não é", tudo tem que ser "não é" alguma hora. Ou tem um outro uso que tenho observado que é assim: trabalha-se a partir da sociotécnica, mas é muito interessante como não se lê, não se usam os clássicos da sociotécnica.

A - Tudo que cai nos Estados Unidos, eles americanizam, quando você vai ver a citação é o "John Smith" que diz aquilo. Eu leio as quatro linhas mais kleinianas da minha vida e vou ver a citação é o "John Smith" que disse aquilo. Eles batizam e rebatizam: não é mais grupo semi-autônomo de trabalho, mas é ilha de produção etc.

L - Tem um artigo do Peter Spink em que ele se refere a você - A organização como fenômeno psicossocial: notas para uma redefinição da psicologia do trabalho ${ }^{39}$ - e diz que você observa que os cursos de psicologia do trabalho vão seguindo a história da atividade que a psicologia foi tendo, cronologicamente...

A - Mas ninguém diz isso. Quando eu cheguei na GV, procurei a Maria Olívia Penteado, que é uma amiga do Sigmar Malvezzi, que se ofereceu para me ajudar e trouxe-me diversos programas de disciplinas de diversas faculdades, o próprio Sigmar ajudou-me. Eu consigo programas da própria GV. Não só na GV, mas em muitos lugares o programa é assim: Psicologia Aplicada à Administração e os tópicos: 1) Seleção, 2) Treinamento, 3) Grupo informal, 4) Liderança, 5) Motivação, 6) Teoria de Argyris, 7) Teoria de Herzberg, 8) Conflito e resistência à mudança. Eu fiz uma ementa quase na hora de sair da GV. Aquela ementa está boa. Isso deve estar no MEC. Só quando o Peter veio é que eu olho para aquilo e digo: "já sei!". Só quando eu consigo mapear as teorias é que eu consigo ler a teoria gerencial americana. Aí, eu digo: "que engraçado, é cronológico". Mas nenhum professor diz isso. Aquilo é contado como mito. Aliás, tem uma tese na GV (parece que é boa) que trata o taylorismo como mito. Isto é, como uma verdade eterna, que não é datada, que não nasceu da cabeça de ninguém e que não vai morrer (o taylorismo lá, no primeiro ano, é tratado

${ }^{39}$ Publicado em Psicologia E Sociedade, 8 (1), 174-192, 1996. 
assim...). Taylor é a coisa científica, pois ele não é capaz de dizer uma só frase sem pôr a palavra "ciência" ou "científico". Ele gosta tanto de ciência que deveria ter estudado... [risos]. A ciência prá ele é sinônimo de ciência analítica. A ciência, até a metade do século XIX, é isso, é analítica... é decomposição mesmo. O objeto nunca pode ser estudado na forma em que ele se apresenta na experiência porque ele é muito complexo com muitas coisas misturadas. Fragmenta-se e chega-se ao elemento. $\mathrm{O}$ elemento sim seria suficientemente simples e puro para poder ser estudado. Esse é o procedimento analítico-sintético. E na síntese você vai ver quais são as leis de combinação dos elementos. Isso é a ciência até a metade do século XIX. Quando Taylor diz que o elemento na fábrica é o homem-tarefa, é a menor unidade humana com a menor tarefa (esse é um elemento duplo, como estímuloresposta), aí chegou-se à pureza, como em química, ao indivisível... um "homenzinho" com a sua "tarefinha", a mais simples possível porque você já decompôs tudo. Na Física é o atomicismo... a Biologia é molecular, na Medicina são os germes, vírus, bactérias...

L - Mas você falava que, quando o Peter veio, ele deu esse seminário para os professores e os cursos de pós-graduação, aí que você conseguiu entender cada uma dessas coisas que você não conseguia ler antes. Mas isso é porque você estudou a sociotécnica?

A - A sociotécnica é um grande condensado de críticas. É como a gestalt, ela nasce como um condensado de críticas às escolas anteriores. Ela já nasce sabendo o que está fazendo. A partir da sociotécnica, através de suas críticas, eu compreendo porque eu não gostava, porque eu não conseguia ler aquelas coisas que eu só tinha visto como ordem cronológica. Eu consigo perceber, então, qual é o papel de cada uma, o que cada autor faz com essas teorias. Agora, por mais irônico que possa parecer para vocês, cada um chega e aprofunda-se mais na psicologia. Sim senhores, podem levar um susto! É assim mesmo. A teoria da motivação é só psicologia... ela se transforma numa verdadeira psicologia. Verdadeira entre aspas. A partir da escola de relações humanas, a teoria da motivação vem endossar, engrossar e aprofundar mais a idéia de que, paradoxalmente, a organização é só o ser humano. E não é! Organização não é só o ser humano. Além disso, para essa escola, o mundo acaba nos portões da fábrica! Mas ela é a que mais fala do homem, mas é a que mais fala do homem adaptativamente. Você vai vendo que, à medida que vai fracassando o que eles fazem em relação ao ser humano - que eles chamam de recursos humanos, é claro - eles são obrigados a aprofundar no psíquico e vão cair até em psicanálise por causa dos seus fracassos. É uma história de fracassos e a história das teorias de organizações é uma história de remendos ao taylorismo. Ninguém tem coragem de jogá-lo fora. Com toda a crítica que existe - principalmente na sociologia de esquerda e não é brincadeira a bibliografia que existe você não encontra uma proposta alternativa. Você encontra no Herzberg uma coisa que o Friedman mais ou menos copia, que é juntar três tarefas monótonas ou alternar de uma monótona para outra para acabar com a monotonia. É o Peter que diz, ironicamente: "trocar de uma tarefa monótona para outra tarefa monótona acaba com a monotonia?" [risos]. Mas ninguém pega as raízes do taylorismo. Ninguém mexe com a primeira hipótese operativa de Taylor. Nós vemos isso na tese de doutorado do Afonso Fleury, que é uma obra-prima (na verdade, o meu curso era montado em cima dessa tese). Ninguém mexe nas três primeiras hipóteses de Taylor, que são hipóteses de "como fazer". Só a quarta hipótese, que é a hipótese do humano - bem ou mal Taylor via o humano e o técnico. A partir da escola de relações humanas (estou citando o Peter Spink), temos um abismo entre a parte técnica e a parte humana. Passam a ser tipos diferentes de especialistas que cuidam de cada uma dessas divisões. Ciências diferentes cuidam de cada uma e o abismo é total, até o infinito. Nunca mais ninguém lê as duas partes juntas. Isso até 1960, um pouco antes de 1960, quando aparece a escola sociotécnica. Ou, talvez, com o Argyris que levanta que o trabalho é uma droga, mas quando propõe soluções, elas também são uma droga. Ou o Herzberg que faz o enriquecimento das tarefas. Pelo menos o Herzberg lembra que tem trabalho, porque você lê tudo da escola de relações humanas e ninguém fala uma frase sobre tarefa. Você não sabe se estão falando de um clube atlético, de uma igreja ou de uma seita. A escola sociotécnica não 
foi um desenvolvimento linear a partir dessas coisas. Nas ciências exatas não há memória, as coisas são jogadas fora e a última teoria aparece. A única vez que nas exatas as teorias vigoram ao mesmo tempo é agora, quando temos a física newtoniana e a física relativista juntas. A única vez que se mantém a história porque nas ciências exatas você joga fora as teorias, como erradas.

L - Você falou em um determinado momento que vai decompondo, decompondo, decompondo e decompõe inclusive o que vão ser as especialidades. Existem ementas de disciplinas em cursos de psicologia, disciplinas inteiras que vão falar de seleção, outras de treinamento e desenvolvimento, só que você não tem uma discussão, por exemplo, de teoria de organização antes.

A - Claro!

L - Entra na técnica, direto!

A - E por que seleção, treinamento entram nessa lista? São as coisas do Taylor, são as coisas mais importantes do taylorismo. A tarefa não mudou. Você, na verdade, vai selecionar o homem partido para fazer a tarefa elementar. Você tem dois homens partidos: aquele que só faz e não pensa e aquele que só pensa e não faz. O pessoal do planejamento não desce para a fábrica porque os operários gozam deles. Engenheiro que vai para a fábrica é engenheiro que entrou na semana passada. Passados dois meses, ele não vai para o chão de fábrica de jeito nenhum. Ele é da turma que só pensa e não faz.

L - E fica a impressão de que as pessoas são assim mesmo, não é? Existe a idéia de que o operário que está ali não pensa... É um absurdo porque ele tem que pensar para fazer o que está ali.

A - Se ele não pensasse, não sairia nem a droga de tarefa taylorista, como acontece na operação tartaruga. Ele está dando mais do que se pede. Inclusive, quando matam ele com a tarefa repetitiva, dizem que não estão pagando mais justamente porque ele não precisa pensar. A primeira hipótese do Taylor é a hipótese da fragmentação, que começa com um departamento de planejamento.

L - Tem uma coisa que eu acho que vem toda das teorias de organização e a contribuição de cada uma dessas áreas, da psicologia, por exemplo, é uma contribuição totalmente conformada. Dificilmente você tem uma contribuição que tenha sido significativa da psicologia e que vai pensar essas questões. Parece que é assim, "o que sobrou para a psicologia é isso" e então ela faz o que sobrou.

A - Exatamente. Infelizmente, a psicologia tem uma parte aplicada, os testes e companhia. Por causa disso, ninguém nunca pensa em lançar um olhar psicológico [risos]. Ela fica com aquele quadradinho do organograma onde eles penduram um psicólogo. Ele nem conhece o resto...

L - Mas eu acho que, pior do que ele estar lá no quadradinho, só na empresa, é que esse quadradinho vem para a academia.

A - Claro, claro. A velha briga que eu tinha na GV era essa, a de preparar para o mercado. Eu dizia: "Não, então fechem todas as universidades!". Se elas não forem uma vanguarda, se elas não estiverem pensando o que vai acontecer daqui a dez anos no mundo, fecha tudo! Eu falava para os meus alunos: "Você aprende mais saindo daqui hoje e virando office-boy, mais do que em quatro anos aqui. Com quatro anos como office-boy você vai aprender muito mais. Vai ser capaz de conseguir uma promoçãozinha e virar chefe de almoxarifado"... Adoro almoxarifado!

Bem, retomando, o meu curso, então, quando eu chego com esse meu programa, que eu pego o veio da tarefa, eu pego só a relação homem-tarefa à qual subjaz uma teoria do homem, explícita ou implícita... Então, uma frase que eu fiz foi assim: toda teoria de 
organização desenha à sua maneira a relação homem-tarefa e a toda relação homem-tarefa subjaz uma definição do homem. Assim, eu expunha esse programa, tudo isso em seis meses, e mandava eles lerem aquilo que eu traduzi. Quando eu trouxe isso, os meninos resistiram brutalmente porque eles tinham estudado três meses de Taylor antes. Eu começava o curso dizendo: "eu não sou comunista, eu não sou humanista-cristã", mas eles cheiravam e resistiam brutalmente, defendiam o Taylor com vigor. Vocês não sabem o vigor! Quando eu dava o programa de educação continuada, eu só não era linchada porque tinha a equipe das secretárias lá fora. Eles queriam me matar! Quando eu cheguei com esse programa, os quatro alunos que estudam ficaram alvoroçados e perguntaram para o professor de produção: "Professor, e esse negócio de sociotécnica?" e o professor: "Ah, isso não deu certo. Isso já foi experimentado e não deu certo".

L - E tem uma coisa de que a "sociotécnica não dá certo" ou que é "ultrapassada"...

A - "Que é uma beleza, mas é ultrapassado" ou "esse treco não dá certo no Brasil porque o nosso operário é analfabeto"... Eu acho que a teoria de organizações não é linear, não nego que se possa explorar uma teoria enquanto outra continua. Mas a escola sociotécnica foi picada. As coisas que ela diz estão picadas, às vezes estão com apelidos, como "ilha de produção". Tem muita coisa picada.

L - Eu acho que tem essa coisa de ser picada e de se utilizar sinônimos... e de pasteurizar, retirar a dimensão de interesses diferentes e de conflitos. A escolha organizacional, o grupo semi-autônomo...

A - E essas coisas são a escola sociotécnica. Você não vai ver a palavra "motivação" em nenhuma linha da escola sociotécnica, a não ser que seja para criticar. Porque, na verdade, motivação é uma isca para o peixe morder e o que a escola sociotécnica propõe é que você melhore de fato o trabalho. Eu contava para os meus alunos uma piada assim: "Tinha a mãe que tinha um filhinho que não comia. Ela o leva a um primeiro pediatra e ele receita um remedinho para abrir o apetite. Não dá certo. Ela leva a um segundo pediatra e receita um outro remédio. Não dá certo. Aí, ela leva a um terceiro pediatra e ele pergunta: 'a senhora já tentou melhorar a sua comida?"” [risos]. E o psicólogo se transformou nessa triste figura que ajuda a engrupir operário. O Peter disse uma coisa que eu amei (operário inglês é fogo, não é?): eles faziam piadas de "políticas em RH" que mudavam constantemente, perguntavam um para o outro: "What is the flavor of the month?". Porque é sempre em ondas. São ondas de verdade. Onda como é por essência: ela cresce, estoura e morre na praia, enquanto ela morre tem outra nascendo logo ali. É isso. Nesses departamentos de RH é assim, quem chega com a última onda... se bem que última onda é relativo, pois até Maslow faz sucesso...

L - É, eu acho que ele faz mesmo. Tem que olhar o "coitadinho", tem que olhar o "lado humano"...

A - O Júlio Lobos tem um artigo sobre motivação no qual ele se pergunta porque a idéia de motivação pega tanto. Ele diz: por causa do seu bom senso. Eu acho que não. Eu acho que é uma maneira muito subjacente de conseguir explicar e conseguir perseverar a injustiça social. Aquela idéia de que "ele não sofre porque não está nem precisando disso". O Maslow tem um trecho que é triste mesmo: quem não conseguiu satisfazer $90 \%$ das necessidades de caráter mais básico, não chegaria a querer... a precisar satisfazer as outras! Eu até acredito que uma pessoa com problemas financeiros graves é capaz de abandonar todo o resto para se dedicar só àquilo naquele momento, então pára com futebol, pára com o resto, mas dizer que ele não precisa?! Você está criando uma sub-espécie! Isso serve para justificar o seguinte: "para que vou dar caviar para o sujeito, se ele vai detestar, vai vomitar? Ele nem sabe que isso existe!".

L - E essa teoria da hierarquia de necessidades de Maslow é muito utilizada... Eu vi, o 
Fábio também, uma consultora de empresas que se utilizava dessa teoria para explicar o homem no trabalho... E é uma psicologia prescritiva, não é?

A - Toda a psicologia do trabalho é prescritiva. E dizer que é prescritiva, falando de ciência, é muito pejorativo. Você tem a prescritiva, a normativo-prescritiva que também é pejorativa... Mas você precisaria chegar à teoria explicativa.

L - E tem muito do que se fala que é do âmbito do psicológico e que não são os psicólogos que falam. É aquilo que você chama de "psicologia home made".

A - Tem uma psicologia que eles inventam. Eu dizia: "já que vocês gostam de psicologia, por que vocês não estudam um pouco?”. É uma psicologia que eles inventam, horrorosa! Parece um pouco com o behaviorismo. É aprendizado, mas muito capenga... O Skinner e os behavioristas fazem um esforço para construir uma teoria e eles vêm dizer que é aprendizado, mas não dizem de que tipo, como se dá, o quê é. Eu agora estou lendo esse novo livro do Dejours - A banalização da injustiça social ${ }^{40}$ - e parece que o que nós dizíamos até a década de 80 já não vale mais. Ele diz que vai trabalhar com um conceito da Hannah Arendt. Ele diz que esse novo movimento da globalização é a terceira guerra mundial, que é uma guerra econômica entre nações e que o objetivo é a pura competitividade, é para destruir o outro, entre as empresas e as nações. O que ele quer saber é como se dá o consentimento, ele não usa essa palavra, mas eu adoro essa palavra, como é que se dá o consentimento dos que sofrem com os efeitos dessa coisa e consentem com ela. E aqui ele diz que os que sofrem, assim como os que infligem sofrimento aos outros, estão completamente arraigados e engajados nessa guerra. Então, ele se pergunta, como você chama de adversidade, uma coisa que na verdade é injustiça? Nessa mudança, o protesto desaparece. Na verdade, a adversidade não é construída pelos seres humanos, é esse o ponto. Se você pensasse a coisa como injustiça, ela passa a ser histórica, pois é construída pelos seres humanos. E a adversidade não é. Então, vai-se embora a culpa...

L - E a maioria dos textos dessa área de trabalho procura usar termos que fogem dessa... procuram usar outros que são eufemismos, como se as coisas fossem naturais etc.

A - Claro! E o Dejours diz que a banalização do mal passa por várias fases intermediárias e cada uma das quais depende de uma construção humana. Ele diz como é que em 1980 aconteceram greves e hoje não se consegue mais nada. Ele diz que isso ocorre porque este operário não é mais aquele. Esse pedaço me assustou! Tem algo novo aí... fala que há uma crescente tolerância à injustiça. Há uma transformação qualitativa da sociedade.

L - Arakcy, eu queria que você falasse um pouco - eu não queria deixar de perguntar, até demos a esta revista o nome de Cadernos de Psicologia Social do Trabalho disto: você fala em psicologia social das organizações...

A - Sim, falo. Está no nome das matérias quando as batizo... (imagine que a matéria chamava-se Psicologia Aplicada à Administração e a matéria do mestrado chamava-se Psicossociologia Industrial e do Trabalho. Piada, é o país da piada pronta, como diz o Zé Simão $\left.{ }^{41}\right)$. Claro, para mostrar que é humana e social, que tem que se apoiar em uma psicologia social. Vejam, aparentemente, a teoria gerencial americana chega a aprofundamentos, eles vão se aprofundando e em psicanálise sofisticada às vezes. Infelizmente, a psicanálise trouxe consigo, ao ser introduzida na empresa, a visão individual, o que combinou muito com o taylorismo. Então, se a moça não está se dando bem com o chefe, seria porque o bigode dele lembra o bigode do pai. Quer dizer, realmente... deveria haver uma lei proibindo esse tipo de coisa [risos]... Então, o psicólogo faz esse tipo de coisa e,

40 Publicado pela Editora da Fundação Getúlio Vargas, Rio de Janeiro, em 1999.

${ }^{41}$ Colunista do jornal Folha de S. Paulo. 
como tem uma parte da psicologia que é aplicada e é aplicável, o resto da psicologia é esquecida, principalmente a psicologia social. Mas é a psicologia social que tem que entrar nesse lugar! Apoiada numa certa psicologia e coerente com uma certa sociologia. Psicologia social não mantém... ela não está estudando o universal e toda hora você a lê como se fosse universal: "as pessoas têm preconceitos contra negros": Quem? As pessoas quem? Ou "as representações de tal”. Mas as representações sociais de quem? Então, você tem de estar apoiada numa sociologia para não fazer essas generalizações idiotas em uma sociedade tão hierarquizada como a nossa. Ainda mais uma sociedade tão misturada etnicamente... Brincar de universais? Se eu acho que até os psicanalistas têm que parar de brincar de universais, imagine os psicólogos do trabalho!

L - Mas quando você fala de uma psicologia social, isso já é difícil, pois tem várias coisas que são psicologia social...

A - Bom, ninguém sabe o que é psicologia social! Isso permite que a gente faça um monte de coisas... E a psicologia social abdicou de seus grandes temas. Ficou amarrada à metodologia, amarrada aos seus primeiros temas, ficou amarrada pela sua própria história. Ela é amordaçada pelos seus primeiros anos. Aquilo virou definição. Não pode! Uma ciência não pode se definir pelos temas e pela metodologia que usou nos seus primeiros tempos. Isso paralisa, impede qualquer crescimento! Podia ser uma maneira de olhar, podia ser o uso de alguns métodos. Agora, temas? E nós ficamos com o menor (nós importamos todos os nossos temas maiores)! Nós ficamos com relações interpessoais. Pelo amor de Deus! Influência do grupo sobre o indivíduo? Pelo amor de Deus! Identidade... de quem? Ninguém pergunta! Socialização... de quem? Uma criança de três anos nas classes baixas já é grandinha, já pode tomar conta dos mais novos. Nas classes altas é um nenê, está de chupeta e fralda...

Mas até que a escola de relações humanas fez psicologia social. $\mathrm{O}$ grupo que baixou na Western Eletric fez isso, só que fez psicologia social sem trabalho [risos]. As únicas teorias que usaram a psicologia para valer foram a escola de relações humanas e a teoria de motivação. E os psicólogos empacaram ali e não saem porque lá eles têm mais o que fazer e dizer. Eles não saem mais dessa! Isso eu vejo por algumas pessoas que ficam nessa área de psicologia do trabalho. Então, o psicólogo ficou muito atrelado a isso porque foram verdadeiramente as teorias que deram importância a ele.

L - O Peter fala uma coisa interessante naquele mesmo texto em que ele cita você. $\mathrm{O}$ seguinte: as organizações não são uma fonte de problemas que precisam ser resolvidos. Por isso não podem ser um objeto para uma psicologia aplicada. Mas as organizações devem ser um fenômeno que merece ser estudado. Isso confere uma grande diferença de olhar e dos tipos de possibilidade de investigação e de atuação.

$$
\text { A - Concordo inteiramente. }
$$

